Composition and stability constants of copper(II) complexes with succinic acid ions determined by capillary electrophoresis

Viktoria V. Sursyakova ${ }^{1 *}$, Galina V. Burmakina ${ }^{1,2}$, Anatoly I. Rubaylo ${ }^{1,2,3}$

${ }^{1}$ Institute of Chemistry and Chemical Technology of the Siberian Branch of the Russian Academy of Sciences, Krasnoyarsk, Russia

${ }^{2}$ Siberian Federal University, Krasnoyarsk, Russia

${ }^{3}$ Krasnoyarsk Scientific Centre of the Siberian Branch of the Russian Academy of Sciences, Krasnoyarsk, Russia

(Received 2016; accepted 2016)

*Correspondence: Dr. Viktoria V. Sursyakova, Institute of Chemistry and Chemical Technology SB RAS, Akademgorodok 50/24, 660036 Krasnoyarsk, Russia

E-mail: viktoria_vs@list.ru

Fax: 73912494108 


\section{Composition and stability constants of copper(II) complexes with succinic acid ions determined by capillary electrophoresis}

The advantage of usage of capillary electrophoresis technique was demonstrated for studying a complicated system owing to the dependence of direction and velocity of the electrophoretic movement on the charge of complex species. The stability constants of copper(II) complexes with ions of succinic acid were determined by capillary electrophoresis, including the 1:2 metal to ligand complexes which are rarely mentioned and taken into account in studies during recent years. The measurements were carried out at $25{ }^{\circ} \mathrm{C}$ and ionic strength of 0.1 , obtained by mixing the solutions of succinic acid and lithium hydroxide up to $\mathrm{pH} 4.2$ - 6.2. It was shown that while $\mathrm{pH}$ was more than 4.5 the zone of copper(II) complexes with succinate ions moves as an anion. It is impossible to treat this fact using only the complexes with a metal-ligand ratio of $1: 1\left(\mathrm{CuL}^{0}, \mathrm{CuHL}^{+}\right)$. The following values of stability constants were obtained: $\log \beta(\mathrm{CuL})=2.89 \pm 0.02$, $\log$ $\beta\left(\mathrm{CuHL}^{+}\right)=5.4 \pm 0.5, \log \beta\left(\mathrm{CuL}_{2}{ }^{2-}\right)=3.88 \pm 0.05, \log \beta\left(\mathrm{CuHL}_{2}{ }^{-}\right)=7.2 \pm 0.3$.

Keywords: succinic acid, capillary electrophoresis, stability constant, $\mathrm{Cu}(\mathrm{II})$ complexes, charge of complex

\section{Introduction}

Copper is a biogenic metal that forms complexes with many ligands among which are ions of succinic acid $\left(\mathrm{H}_{2} \mathrm{~L}\right)$ [1-11]. In a number of studies, the only $\mathrm{CuL}^{0}$ and sometimes $\mathrm{CuHL}^{+}$ complexes are mentioned for the copper(II) - succinic acid system [12-15]. The well-known database based on the six-volume book by A.E. Martell and R.M. Smith, NIST Critically selected stability constants of metal complexes (Database 46 free downloaded from www.nist.gov/srd/nist46.cfm), contains only the stability constants for these complexes too. In addition, in a few recent papers [16-19], while complicated systems are studied including the ions of copper(II) and succinic acid, only these complexes are taken in consideration. At the same time, the IUPAC Stability constants database (Mini-SCDatabase free downloaded from http://www.acadsoft.co.uk/scdbase/scdbase.htm) contains the stability constant values for the 1:2 metal to ligand complexes, apart from those for the 1:1 complexes [20].

Such nature of the data can be related to methods used for the determination of composition and stability constants. In majority of the methods, the measuring properties are independent or slightly dependent on the charge of complex species. The electromigration 
methods have advantage over other methods owing to the dependence of direction and velocity of the electrophoretic movement on the charge of complex species. Labile complexes produce one peak in electropherogram, the effective electrophoretic mobility $\mu_{\text {eff }}$ of which is the average weighted over mole fractions of species [21]:

$$
\mu_{\text {eff }}=\sum_{i}^{n} \mu_{i} \cdot \alpha_{i}, \alpha_{i}=\frac{\left[M L_{i}\right]}{C_{M}}=\frac{\beta_{i}[L]^{i}}{1+\sum_{i}^{n} \beta_{i}[L]^{i}}, i=0,1 \ldots \mathrm{n}
$$

where $\mu_{i}$ is the ionic mobility of $i^{\text {th }}$ species (for anions $\mu_{i}<0$ ), $\alpha_{i}$ denotes the mole fraction of $i^{\text {th }}$ species, $\left[M L_{i}\right]$ is the equilibrium concentration of the complex $M L_{i}, C_{M}$ denotes the total concentration of the metal, $[L]$ means the ligand concentration into BGE, $\beta_{i}$ means the stability constant of the complex $M L_{i}$. Similarly, the effective charge of the complex zone can be calculated as follows:

$$
z_{\text {eff }}=\sum_{i}^{n} z_{i} \cdot \alpha_{i}
$$

where $z_{i}$ is the charge of $i^{\text {th }}$ species.

The capillary electrophoresis (CE) is most widespread among the electromigration methods. CE appeared in the 1980s and was rapidly developed due to transition to the silica capillaries with very small and regular diameters (tens of micrometers) and application of the straight detection in the fluid flow [22]. The CE and related electroseparation techniques are widely used for the estimation of stability constants because of rapidity, low cost of reagents, and high performance [23-31]. To study the interactions between a metal and ligand, several electropherograms are recorded with varying ligand content in background electrolytes (BGE) and metal solution injected as a sample. On basis of the effective electrophoretic mobilities of metal complexes and ligand concentrations in BGEs, the stability (formation, association or binding) constants are calculated. Sometimes, a metal solution is added to BGE and ligand is injected as a sample. 
The CE and related electroseparation techniques were used for the determination of the stability constants of the copper(II) complexes with proteins [27, 32-33], nitrilotriacetate and cysteine [34], $\alpha$-hydroxyisobutyric acid and sulfate ions [21]; constants of $\mathrm{Cu}(\mathrm{II})$ - alizarin complexone with amines [35], etc. The copper(II) complexes are also employed in CE for the metal determination [24] and in ligand-exchange CE for the separation of different organic analytes [36-40], including enantiomers [37]. But the CE technique has not been used early for studying the copper(II) complexes with succinic acid ions. The purpose of this study was to explore the copper(II)-succinic acid system and determine the stability constant values using CE.

\section{Experimental}

\subsection{Instrumentation}

The study was carried out using a capillary electrophoresis system with a diode-array detector Agilent ${ }^{3 \mathrm{D}} \mathrm{CE}$ G1600A (Agilent Technologies, Waldbronn, Germany) of the Krasnoyarsk Regional Center of Research Equipment, Siberian Branch of the Russian Academy of Sciences. An untreated fused silica capillary with $50 \mu \mathrm{m}$ id and the total and effective lengths of 48.5 and $40 \mathrm{~cm}$, respectively, was used (Agilent Technologies). The capillary temperature was kept constant at $25.00 \pm 0.04{ }^{\circ} \mathrm{C}$. The data acquisition and processing were performed with the computer program ChemStation Rev.A.10.02. The separation was achieved by applying a voltage of $+9-10 \mathrm{kV}$ so that for each BGE the product of voltage and current was kept constant

(Table 1). The detection wavelengths were 254 and $191 \mathrm{~nm}$. The hydrodynamic pressure of 50 mbar was used to inject samples for $2 \mathrm{~s}$ and to reduce migration time during the separation [4144].

A new capillary was first flushed with $1 \mathrm{M} \mathrm{NaOH}$ for $10 \mathrm{~min}$, then with ultra pure water for $10 \mathrm{~min}$. At the beginning of each day, the capillary was first flushed with $0.1 \mathrm{M} \mathrm{NaOH}$ for 5 min, twice with ultra pure water for $10 \mathrm{~min}$ and with running BGE for $15 \mathrm{~min}$. Between the runs the capillary was flushed with BGE for 5 min.

All the $\mathrm{pH}$ measurements were made using a calibrated precise $\mathrm{pH}$ instrument «Expert001-1» (Econix-Expert, Moscow, Russia) with a precision of $0.005 \mathrm{pH}$ units. 


\subsection{Chemicals}

Succinic acid ( $\geq 99.5 \%$ ), copper(II) chloride ( $\geq 99.0 \%$ ), lithium hydroxide monohydrate (99.95\%), and dimethyl sulfoxide (DMSO) ( $\geq 99.5 \%)$ were purchased from Sigma-Aldrich (Moscow, Russia). Deionized water with electrical conductivity less than $0.1 \cdot 10^{-6} \mathrm{~S} \cdot \mathrm{cm}^{-1}$ from a water purification system Direct-Q3 (Millipore, France) was used for solution preparation. DMSO was used as a marker of electroosmotic flow (EOF). A stock solution of copper(II) chloride was prepared with a concentration of $100 \mathrm{mM}$, a stock solution of DMSO was prepared with a concentration of $10 \%(\mathrm{v} / \mathrm{v})$. Samples consisted of $1 \mathrm{mM}$ copper(II) chloride and $0.05 \%$ (v/v) DMSO were daily prepared by diluting the above stock solutions with BGEs.

\subsection{Measurements and data processing}

The measurements were carried out using BGEs on basis of succinic acid $\left(\mathrm{H}_{2} \mathrm{~L}\right)$ with the addition of lithium hydroxide up to $\mathrm{pH} 4.2$ - 6.2. For this $\mathrm{pH}$ range, succinic acid can be used as a single buffering constituent with acceptable buffer capacity because $\mathrm{pK}_{\mathrm{a} 1}, \mathrm{pK}_{\mathrm{a} 2}$ at $\mathrm{I}=0.1$ and $25{ }^{\circ} \mathrm{C}$ are $3.99 \pm 0.02$ and $5.24 \pm 0.04$ from NIST and 3.99 and 5.20 from IUPAC databases (in this study, the data from IUPAC databases were used). The ligand concentration was varied by changing the $\mathrm{pH}$ values of BGEs. In order to fix the values of stability constants, the ionic strength was maintained at the constant value of 0.100 (Table 1). For BGE, the ionic strength was calculated by using equation 3 (concentration of $\mathrm{OH}$ ions was negligible in the studied $\mathrm{pH}$ range):

$$
I=1 / 2 \sum_{i} z_{i}^{2} C_{i}=1 / 2\left(\left[H^{+}\right]+\left[L i^{+}\right]+\left[H L^{-}\right]+4\left[L^{2-}\right]\right)
$$

The electroneutrality equation was expressed as follows:

$$
\left[\mathrm{H}^{+}\right]+\left[\mathrm{Li}^{+}\right]=\left[\mathrm{HL}^{-}\right]+2\left[\mathrm{~L}^{2-}\right]
$$

Combination of equations 3 and 4 gave $I=\left[H L^{-}\right]+3\left[L^{2-}\right]$. Taking into account

$$
\left[\mathrm{HL}^{-}\right]=C_{L} \cdot \alpha_{\mathrm{HL}^{-}} \text {and }\left[\mathrm{L}^{2-}\right]=C_{L} \cdot \alpha_{L^{2-}}
$$

where $C_{L}$ is the total concentration of succinic acid in BGE, the ionic strength was calculated as follows: 


$$
\mathrm{I}=C_{L} \cdot \frac{\left[\mathrm{H}^{+}\right] \mathrm{K}_{\mathrm{a} 1}+3 \mathrm{~K}_{\mathrm{a} 1} \mathrm{~K}_{\mathrm{a} 2}}{\mathrm{~K}_{\mathrm{a} 1} \mathrm{~K}_{\mathrm{a} 2}+\left[\mathrm{H}^{+}\right] \mathrm{K}_{\mathrm{a} 1}+\left[\mathrm{H}^{+}\right]^{2}}
$$

where $K_{a 1}, K_{a 2}$ are the acidity constants of succinic acid of $1^{\text {st }}$ and $2^{\text {nd }}$ steps, respectively, $\left[H^{+}\right]=10^{-p H} / \gamma_{H^{+}}$. The activity coefficients $\gamma_{H^{+}}$were calculated using the extended DebyeHückel expression [45] (equation 29) with the effective diameter of the hydrated $\mathrm{H}^{+}\left(\mathrm{H}_{3} \mathrm{O}^{+}\right)$of 9 $\AA$. Thus, the total concentration of succinic acid in BGE $C_{L}$ was calculated as follows (Table 1):

$$
C_{L}=I \cdot \frac{\mathrm{K}_{\mathrm{a} 1} \mathrm{~K}_{\mathrm{a} 2}+\left[\mathrm{H}^{+}\right] \mathrm{K}_{\mathrm{a} 1}+\left[\mathrm{H}^{+}\right]^{2}}{\left[\mathrm{H}^{+}\right] \mathrm{K}_{\mathrm{a} 1}+3 \mathrm{~K}_{\mathrm{a} 1} \mathrm{~K}_{\mathrm{a} 2}}
$$

For the system under study, the following equilibria were considered:

$$
\begin{aligned}
& \mathrm{Cu}^{2+}+\mathrm{L}^{2-} \leftrightarrows[\mathrm{CuL}]^{0} \\
& \mathrm{Cu}^{2+}+2 \mathrm{~L}^{2-} \leftrightarrows\left[\mathrm{CuL}_{2}\right]^{2-} \\
& \mathrm{Cu}^{2+}+\mathrm{H}^{+}+\mathrm{L}^{2-} \leftrightarrows[\mathrm{CuHL}]^{+} \\
& \mathrm{Cu}^{2+}+\mathrm{H}^{+}+2 \mathrm{~L}^{2-} \leftrightarrows\left[\mathrm{CuHL}_{2}\right]^{-} \\
& \quad \beta_{\mathrm{CuH}_{x} L_{y}}=\frac{\left[\mathrm{CuH}_{x} L_{y}\right]}{\left[\mathrm{Cu}^{2+}\right]\left[H^{+}\right]^{x}\left[L^{2-}\right]^{y}}, \mathrm{x}=0 \text { or } 1, \mathrm{y}=1 \text { or } 2
\end{aligned}
$$

The mole fractions of the hydroxo complexes $\mathrm{Cu}(\mathrm{OH})_{i}$ under the studied conditions were negligible. The stability constants of hydroxo complexes $\mathrm{Cu}(\mathrm{OH})_{i}$ were taken from IUPAC Stability constants database at $25^{\circ} \mathrm{C}$ and $\mathrm{I}=0: \log \beta_{1}=6.3, \log \beta_{2}=10.7, \log \beta_{3}=14.2, \log \beta_{4}=$ 16.4. The values were recalculated by means of the extended Debye- Hückel expression for the ionic strength of 0.1 [45]. Taking into account that the ionic mobility of [CuL] $]^{0}$ equaled to zero, equation 1 for the studying system was expressed as follows:

$$
\begin{gathered}
\mu_{e f f}=\frac{\mu_{\mathrm{Cu}^{2+}}+\mu_{\mathrm{CuL}_{2}^{2-}} \beta_{\mathrm{CuL}_{2}^{2-}}\left[L^{2-}\right]^{2}+\mu_{\mathrm{CuHL}^{+}} \beta_{\mathrm{CuHL}^{+}}\left[H^{+}\right]\left[L^{2-}\right]+\mu_{\mathrm{CuHL}_{2}^{-}} \beta_{\mathrm{CuHL}_{2}^{-}}\left[H^{+}\right]\left[L^{2-}\right]^{2}}{1+\beta_{\mathrm{CuL}^{0}}\left[L^{2-}\right]+\beta_{\mathrm{CuL}_{2}^{2-}}\left[L^{2-}\right]^{2}+\beta_{\mathrm{CuHL}^{+}}\left[H^{+}\right]\left[L^{2-}\right]+\beta_{\mathrm{CuHL}_{2}}\left[\mathrm{H}^{+}\right]\left[L^{2-}\right]^{2}} \\
{\left[\mathrm{~L}^{2-}\right]=C_{L} \cdot \alpha_{L^{2-}}=C_{L} \cdot \frac{\mathrm{K}_{\mathrm{a} 1} \mathrm{~K}_{\mathrm{a} 2}}{\mathrm{~K}_{\mathrm{a} 1} \mathrm{~K}_{\mathrm{a} 2}+\left[\mathrm{H}^{+}\right] \mathrm{K}_{\mathrm{a} 1}+\left[\mathrm{H}^{+}\right]^{2}}}
\end{gathered}
$$

The effective electrophoretic mobility from experimental data was calculated as follows: 


$$
\mu_{\text {eff }}=\frac{l \cdot l_{\text {eff }}}{U}\left(\frac{1}{t}-\frac{1}{t_{\text {eof }}}\right)
$$

where $l$ and $l_{\text {eff }}$ are the total and effective capillary lengths, respectively, $U$ is the voltage, $t$ is the migration time, $t_{e o f}$ is the migration time of the EOF marker.

The stability constants and confidence intervals were determined from equation 9 using non-linear regression fitting of the program MS Excel as follows. For each BGE composition, the formulas to calculate the mole fractions of all species and theoretical values of effective electrophoretic mobilities were typed in Excel cells. The formulas contained references to the cells with the values of the stability constants. Thus, changing the stability constants resulted in the change of the mole fractions and electrophoretic mobilities. Then, the formulas for calculation of differences in the theoretical and experimentally measured values of the effective electrophoretic mobilities were typed and the formula for the sum of squares of the differences was composed. Thereafter, the values of the constants were fitted by a method of successive approximations using Excel Solver Add-in so that the sum of squares was as small as possible.

The ionic mobilities of the species were calculated using the theory of Onsager and Fuoss (OF) for the mixtures of electrolytes [46] by the computational tool set ElphoSeparation [47] (Table 2):

$$
\begin{gathered}
\mu_{i}=\left(\left|\mu_{i}^{0}\right|-\left(B_{1} z_{i}\left|\mu_{i}^{0}\right| \sum_{n=0}^{5} C_{n} R_{i}^{(n)}+B_{2}\left|z_{i}\right|\right) \frac{\sqrt{\Gamma}}{1+\frac{B a}{\sqrt{2}} \sqrt{\Gamma}}\right) \cdot \operatorname{sgn}\left(\mu_{i}\right) \\
B_{1}=\frac{e^{3}}{12 \pi} \sqrt{\frac{N_{A}}{(\varepsilon k T)^{3}}}, B_{2}=\frac{e^{2}}{6 \pi \eta} \sqrt{\frac{N_{A}}{\varepsilon k T}}, \Gamma=\sum_{i=1}^{s} c_{i} z_{i}^{2}=2 I
\end{gathered}
$$

$\mu_{i}^{0}$ is the ionic mobility of the $i$-th ion at $I=0, R_{i}^{(n)}$ is the $n$-th component of the vector $R_{i}, \mathrm{C}_{\mathrm{n}}$ is the $n$-th member of a series [46], $\mathrm{Ba} / \sqrt{2}=1.5, e$ is the elementary charge, $N_{A}$ is the Avogadro constant, $\varepsilon$ is the permittivity of the solution (for diluted solution, $\varepsilon$ equals to the product of the dielectric constant of water 78.36 at $25^{\circ} \mathrm{C}$ and permittivity of a vacuum $8.854 \cdot 10^{-}$ 
$\left.{ }^{12} \mathrm{~F} \cdot \mathrm{m}^{-1}[48]\right), k$ is the Boltzmann constant, $T$ is the absolute temperature, $\eta$ is the solution viscosity, and $s$ is the overall number of all the ionic species in the solution. Because the mobility is in proportion to the charge/radius ratio [49] and radiuses of hydrated ions have close values, the assumption was used that $\mu^{\circ}$ of the singly charged ions equaled to $\mu^{\circ}\left(\mathrm{CuOH}^{+}\right)$and $\mu^{\circ}$ of the double-charged ions equaled to $\mu^{\circ}\left(\mathrm{Cu}^{2+}\right)$, assuming the possible inaccuracy of the evaluation through $\mu_{i} \pm 2 \cdot 10^{-9} \mathrm{~m}^{2} \mathrm{~V}^{-1} \mathrm{~s}^{-1}[47]$.

The values of the stability constant of $\mathrm{CuHL}^{+}$defining according to equation 8 were calculated from the values of the NIST database and articles [13, 14] as follows:

$$
\begin{gathered}
\beta_{\mathrm{CuHL}^{+}}=\frac{\left[\mathrm{CuHL} L^{+}\right]}{\left[\mathrm{Cu}^{2+}\right]\left[\mathrm{H}^{+}\right]\left[L^{2-}\right]}=\frac{\left[\mathrm{CuHL} L^{+}\right]}{\left[\mathrm{Cu}^{2+}\right]\left[H L^{-}\right]} \frac{1}{K_{a 2}}=\frac{K_{\mathrm{CuHL}}^{\mathrm{NIST}}}{K_{a 2}} \\
\log \beta_{\mathrm{CuHL}^{+}}=\log K_{\mathrm{CuHL}^{+}}^{\mathrm{NIST}}+p K_{a 2}
\end{gathered}
$$

where $K_{\mathrm{CuHL}^{+}}^{N I S T}$ is the equilibrium constant for the following reaction from NIST database or articles $[13,14]: \mathrm{Cu}^{2+}+\mathrm{HL}^{-} \leftrightarrows[\mathrm{CuHL}]^{+}$

\section{Results and discussion}

The electropherograms of $1 \mathrm{mM}$ copper(II) solution with the addition of $0.05 \%$ DMSO (as a neutral substances, EOF marker) were recorded using the succinic buffers as BGEs with the $\mathrm{pH}$ range of $4.2-6.2$ at $25^{\circ} \mathrm{C}$ and ionic strength of 0.1 (Figure 1). The measurements were carried out at positive voltage polarity using two detection wavelengths, 254 and $191 \mathrm{~nm}$. These wavelengths corresponded to the maxima of the UV spectra of copper(II) solution and DMSO recorded by the diode-array detector of the used CE system. Two wavelengths were used because DMSO did not give a peak in the electropherogram at $254 \mathrm{~nm}$ and the peak of copper(II) complexes was low-intensity at $191 \mathrm{~nm}$.

For the positive voltage polarity, in electropherograms cations are first recorded, then the EOF marker is recorded and thereafter anions appear. As shown in Figures 1 and 2, the zone of copper complexes was cationic if $\mathrm{pH}$ was less than 4.5 , and the zone was anionic if $\mathrm{pH}$ was greater than 4.5. The appearance of the anionic complexes cannot be explained in the network of 
the existence of only the $\mathrm{CuL}^{0}$, $\mathrm{CuHL}^{+}$species. On basis of equation 9 using non-linear regression fitting, the stability constants were calculated (Table 3). Figure 2 shows the experimental points and theoretical curve of the effective mobility versus BGE pH. Figure 3 shows the fraction diagrams for the system of copper(II) - succinic acid as a function of $\mathrm{pH}$.

In Table 3, the stability constants available in literature for the studied system are also shown. The constants were substantially determined by potentiometric titration, but calorimetric titration and polarography were used too. As can be seen in Table 3, the stability constant for $[\mathrm{CuL}]^{0}$ obtained by $\mathrm{CE}$ is in the range of scattering the literature data, but for the other complexes the obtained values are distinguished from literature data. It is not surprising, in principle, that the data obtained on basis of considering two equilibria are distinguished from the data obtained on basis of considering four equilibria because ignoring a number of equilibria would distort the calculated values of stability constants. But this is far from it for the constants from UIPAC mini-SCDatabase (for $[\mathrm{CuL}]^{0}$ and $[\mathrm{CuHL}]^{+}$species), they accurately agree with the data obtained on basis of two equilibria. It is probable that the authors of paper [20] during the calculation used the literature data of these complexes as the basis that is not quite correct because of the above-mentioned. The results obtained by CE seem to be more reliable because in CE the measured property is not only dependent on mole fractions of complex species, but, in contrast to potentiometric titration and other methods, on the charge of complex species too.

\section{Conclusion}

The electrophoretic mobilities of copper(II) complexes with succinate acid ions were measured at $25{ }^{\circ} \mathrm{C}$ and ionic strength of 0.1 within the $\mathrm{pH}$ range of $4.2-6.2$. The zone of copper(II) complexes has been shown to move as a cation or an anion subject to the experimental conditions. These experiments allow one to accurately calculate the stability constants of copper(II) complexes using the set of electrophoretic mobilities, including constants for the 1:2 metal to ligand complexes for which the literature data are contradictory and which are not often taken into consideration in a number of recent studies. 


\section{Disclosure statement}

No potential conflict of interest was reported by the authors.

\section{References}

1. W. Xu, W.-J. Pan, Y.-Q. Zheng. J. Coord. Chem., 66, 4415 (2013).

2. J. Nagaj, K. Stokowa-Sołtys, E. Kurowska, T. Frączyk, M. Jeżowska-Bojczuk, W. Bal. Inorg. Chem., 52, 13927 (2013).

3. R.R. Khoury, G.J. Sutton, D. Ebrahimi, D.B. Hibbert. Inorg. Chem., 53, 1278 (2014).

4. A.S. Bastug, S.E. Goz, Y. Talman, S. Gokturk, E. Asil, E. Caliskan. J. Coord. Chem., 64, 281 (2011).

5. A. Chylewska, M. Ogryzek, L. Chmurzyński, M. Makowski. J. Coord. Chem., 68, 3761 (2015).

6. M. Padmanabhan, S.M. Kumary, X. Huang, J. Li. Inorg. Chim. Acta, 358, 3537 (2005).

7. D. Ghoshal, T.K. Maji, G. Mostafa, S. Sain, T.-H. Lu, J. Ribas, E. Zangrando, N.R. Chaudhuri. Dalton Trans., 1687 (2004).

8. B. Srikanth, P.S. Rao, V.S.S. Rao, C.K. Sastry, G.N. Rao. Chem. Spec. Bioavail., 24, 39 (2012).

9. A. Satyanarayana, D.N. Kenie, P. Shyamala. Acta Chim. Slov., 60, 807 (2013).

10. D.N. Kenie, A. Satyanarayana, P. Shyamala. Chem. Mat. Res., 7, 93 (2015).

11. G.H. Bindu, G.N. Rao. J. Serb. Chem. Soc., 77, 453 (2012).

12. M.M. Khalil, A.M. Radalla, N.M. Abd Elnaby. J. Sol. Chem., 42, 1123 (2013).

13. N.V. Tukumova, T.R. Usacheva, T.T.D. Thuan, V.A. Sharnin. Rus. J. Phys. Chem. A, 88, 1695 (2014).

14. G. Arena, R. Cali, E. Rizzarelli, S. Sammartano. Transition Met. Chem., 3, 147 (1978).

15. M. Yasuda, K. Yamasaki, H. Ohtaki. Bull. Chem. Soc. Japan, 33, 1067 (1960).

16. P. Prapaipong, E.L. Shock, C.M. Koretsky. Geochim. et Cosmochim. Acta, 63, 2547 (1999).

17. J.-O. Kim, Y.-W. Lee, J. Chung. KSCE J. Civil Engin., 17, 1596 (2013).

18. T.D. Orlova, A.V. Katrovtseva, S.A. Bychkova, F.T. Lan. Rus. J. Phys. Chem. A, 85, 225 (2011).

19. I.T. Ahmed. Synthesis And Reactivity in Inorg. and Metal-Org. Chem. 34, 523 (2004).

20. J.R. Morphy, D. Parker, R. Kataky, M.A.W. Eaton, A.T. Millican, R. Alexander, A. Harrison, C. Walker. J. Chem. Soc. Perkin Trans. 2, 573 (1990).

21. P. Janoš. J. Chromatogr. A, 1037, 15 (2004). 
22. J.P. Landers (Ed.). Handbook of capillary and microchip electrophoresis and associated microtechniques, p. 1598, CRC Press, New York (2008).

23. V.V. Sursyakova, G.V. Burmakina, A.I. Rubaylo. J. Chromatogr. Sci., 54, 1253 (2016).

24. O.V. Popova, V.V. Sursyakova, G.V. Burmakina, A.I. Rubaylo. J. Anal. Chem., 70, 198 (2015).

25. O.V. Popova, V.V. Sursyakova, G.V. Burmakina, V.A. Levdansky, A.I. Rubaylo. Dokl. Chem., 461, 67 (2015).

26. S.E. Deeb, H. Wätzig, D.A. El-Hady. Trends Anal. Chem., 48, 112 (2013).

27. C. Jiang, D.W. Armstrong. Electrophoresis, 31, 17 (2010).

28. X. Liu, F. Dahdouh, M. Salgado, F.A. Gomez. J. Pharm. Sci., 98, 394 (2009).

29. Z. Chen, S.G. Weber. Trends Anal. Chem., 27, 738 (2008).

30. M. Gayton-Ely, T.J. Pappas, L.A. Holland. Anal. Boanal. Chem., 382, 570 (2005).

31. K.L. Rundlett, D.W. Armstrong. J. Chromatogr. A, 721, 173 (1996).

32. S. Redweik, C. Cianciulli, M. Hara, Y. Xu, H. Wätzig. Electrophoresis, 34, 1812 (2013).

33. H.A. Alhazmi, S.E. Deeb, M. Nachbar, S. Redweik, H.M. Albishri, D.A. El-Hady, H. Wätzig. J. Sep. Sci., 38, 3629 (2015).

34. B.B. Tewari. J. Chromatogr. A, 1103, 139 (2006).

35. T. Yokoyama, K. Tashiro, T. Murao, A. Yanase, J. Nishimoto, M. Zenki. Anal. Chim. Acta, 398, 75 (1999).

36. J. Yu, W. Aboshora, S. Zhang, L. Zhang. Anal. Bioanal. Chem., 408, 1657 (2016).

37. S. Kodama, A. Yamamoto, S. Aizawa, Y. Honda, K. Suzuki, T. Kemmei, A. Taga. Electrophoresis, 33, 2920 (2012).

38. G. Maccarrone, A. Contino, V. Cucinotta. Trends Anal. Chem., 32, 133 (2012).

39. L.A. Kartsova, A.V. Alekseeva. J. Anal. Chem., 66, 563 (2011).

40. A.V. Alekseeva, L.A. Kartsova. J. Anal. Chem., 66, 651 (2011).

41. V.V. Sursyakova, A.I. Rubaylo. J. Sep. Sci., 38, 690 (2015).

42. V.V. Sursyakova, S.N. Kalyakin, G.V. Burmakina, A.I. Rubaylo. J. Anal. Chem., 67, 783 (2012).

43. V.V. Sursyakova, S.N. Kalyakin, G.V. Burmakina, A.I. Rubaylo. Electrophoresis, 32, 210 (2011).

44. S.N. Kalyakin, V.V. Sursyakova, G.V. Burmakina, A.I. Rubailo. J. Anal. Chem., 64, 398 (2009).

45. S.A. Allison, H. Pei, S. Baek, J. Brown, M.Y. Lee, V. Nguyen, U.T. Twahir, H. Wu. Electrophoresis, 31, 920 (2010).

46. L. Onsager, R.M. Fuoss. J. Phys. Chem., 36, 2689 (1932). 
47. V.V. Sursyakova, G.V. Burmakina, A.I. Rubaylo. Anal. Bioanal. Chem. In Press. DOI: 10.1007/s00216-016-0025-8.

48. D.R. Lide (Ed). Handbook of chemistry and physics, 84th edn, p. 2475. CRC Press, New York (2003-2004).

49. A.R. Timerbaev, O.P. Semenova, O.M. Petrukhin. J. Chromatogr. A, 943, 263 (2002). 


\section{Tables}

Table 1. BGE concentration $(I=0.100 \mathrm{M})$, equilibrium ligand concentration $\left[\mathrm{L}^{2-}\right]$, voltage $U$, current, and product of voltage and current $(190 \pm 5 \mathrm{kV} \cdot \mu \mathrm{A})$.

\begin{tabular}{llllll}
\hline $\mathrm{pH}$ & $\mathrm{C}_{\mathrm{L}}$ & {$\left[\mathrm{L}^{2-}\right]$} & $U$ & current & $U \cdot$ current \\
& $(\mathrm{mM})$ & $(\mathrm{mM})$ & $(\mathrm{kV})$ & $(\mu \mathrm{A})$ & $(\mathrm{V} \cdot \mathrm{A})$
\end{tabular}

\begin{tabular}{llllll}
\hline 4.200 & 146.5 & 6.62 & 9.2 & 20.5 & 189 \\
4.403 & 114.6 & 9.44 & 9.2 & 20.2 & 186 \\
4.700 & 83.9 & 14.6 & 9.4 & 20.2 & 190 \\
4.900 & 69.7 & 18.5 & 9.6 & 20.2 & 194 \\
5.200 & 54.6 & 23.7 & 9.7 & 19.6 & 190 \\
5.397 & 47.9 & 26.5 & 9.8 & 19.4 & 190 \\
5.600 & 43.0 & 28.7 & 10.0 & 19.5 & 194 \\
6.005 & 37.4 & 31.4 & 10.0 & 19.1 & 190 \\
6.200 & 35.9 & 32.0 & 10.0 & 19.0 & 190 \\
\hline
\end{tabular}

Table 2. Calculated values of the ionic mobilities $\mu_{i}\left(10^{-9} \mathrm{~m}^{2} \mathrm{~V}^{-1} \mathrm{~s}^{-1}\right)$ for $\operatorname{copper}(\mathrm{II})$ ions and complexes with ions of succinic acid for the studied conditions $\left(25^{\circ} \mathrm{C}, \mathrm{I}=0.1\right)$.

\begin{tabular}{lllll}
\hline $\mathrm{pH}$ & $\mathrm{Cu}^{2+}$ & {$\left[\mathrm{CuL}_{2}\right]^{2-}$} & {$[\mathrm{CuHL}]^{+}$} & {$\left[\mathrm{CuHL}_{2}\right]^{-}$} \\
\hline 4.2 & 33.8 & -35.3 & 24.4 & -24.8 \\
4.403 & 33.3 & -35.7 & 24.3 & -24.9 \\
4.7 & 32.4 & -36.4 & 24.0 & -25.1 \\
4.9 & 31.8 & -36.9 & 23.9 & -25.2 \\
5.2 & 30.9 & -37.7 & 23.6 & -25.4 \\
5.397 & 30.5 & -38.0 & 23.5 & -25.6 \\
5.6 & 30.1 & -38.3 & 23.4 & -25.6 \\
6.005 & 29.7 & -38.7 & 23.3 & -25.7 \\
6.2 & 29.5 & -38.8 & 23.3 & -25.8 \\
\hline
\end{tabular}

Table 3. Values of $\log \beta$ for the copper(II) complexes with succinic acid ions $\left(25^{\circ} \mathrm{C}, \mathrm{I}=0.1\right)$. PT - potentiometric titration, CT - calorimetric titration, P - polarography.

\begin{tabular}{lllll}
\hline$[\mathrm{CuL}]^{0}$ & {$[\mathrm{CuHL}]^{+}$} & {$\left[\mathrm{CuL}_{2}\right]^{2-}$} & [CuHL $\left._{2}\right]^{-}$ & Method, reference \\
\hline $2.89 \pm 0.02$ & $5.4 \pm 0.5$ & $3.88 \pm 0.05$ & $7.2 \pm 0.3$ & CE (this study) \\
$2.7 \pm 0.1$ & $7.04 \pm 0.36$ & - & - & NIST Database \\
2.59 & 7.03 & 4.30 & 9.59 & Mini-SCDatabase (IUPAC), PT [20] \\
$2.5 \pm 0.1$ & - & - & - & CT [14] \\
2.6 & - & - & - & PT [15] \\
$2.608 \pm 0.006$ & $7.01 \pm 0.3$ & - & - & PT [14] \\
2.85 & 7.08 & - & - & cited in [14] \\
$2.98 \pm 0.02$ & $7.04 \pm 0.4$ & - & - & PT [13] \\
3.20 & - & - & - & cited in [13] \\
$3.22 \pm 0.02$ & - & a & - & PT [12] \\
4.00 & - & 6.57 & - & P, cited in [20] \\
\hline \multicolumn{5}{r}{${ }^{a}$ Could not be determined because of precipitation }
\end{tabular}




\section{Figure captions}

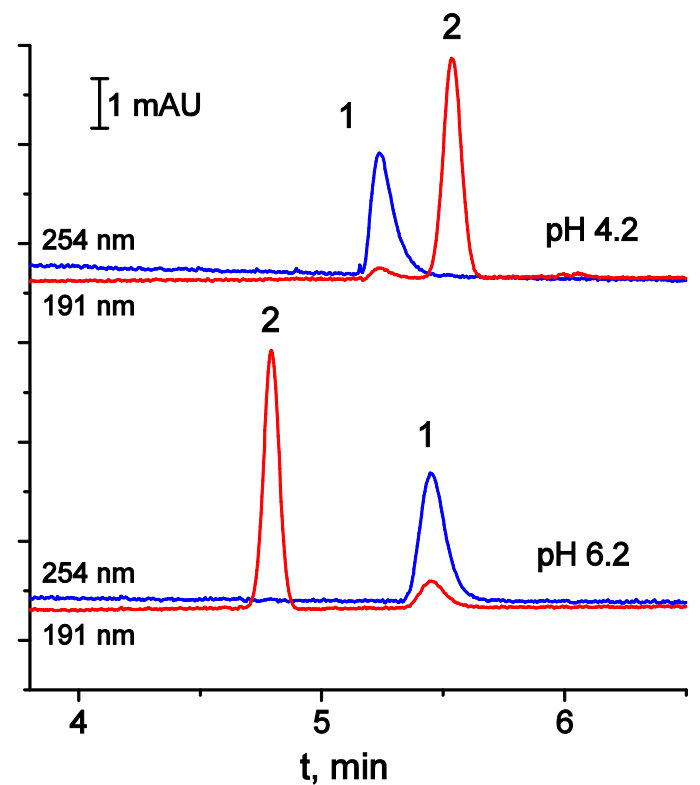

Figure 1. Electropherograms of $1 \mathrm{mM}$ copper(II) solution (1) with $0.05 \%$ DMSO (2) as an EOF marker for BGEs with pH 4.2 and 6.2 (recording at 254 and $191 \mathrm{~nm}$ ).

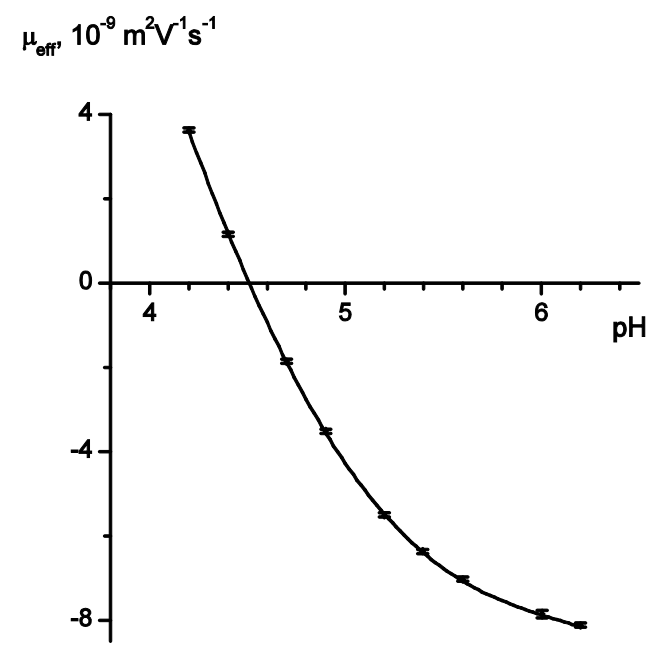

Figure 2. Experimental points and theoretical dependence of the effective mobility of copper(II) on BGE $\mathrm{pH}(\mathrm{I}=0.1)$. The values used for the calculation of the theoretical curve were as follows: $\mathrm{pK}_{\mathrm{a} 1}\left(\mathrm{H}_{2} \mathrm{~L}\right)=3.99, \mathrm{pK}_{\mathrm{a} 2}\left(\mathrm{H}_{2} \mathrm{~L}\right)=5.20 ; \log \beta(\mathrm{CuL})=2.89 \pm 0.02, \log \beta\left(\mathrm{CuHL}^{+}\right)=5.4 \pm$ $0.5, \log \beta\left(\mathrm{CuL}_{2}{ }^{2-}\right)=3.88 \pm 0.05, \log \beta\left(\mathrm{CuHL}_{2}{ }^{-}\right)=7.2 \pm 0.3$. 
Species, \%

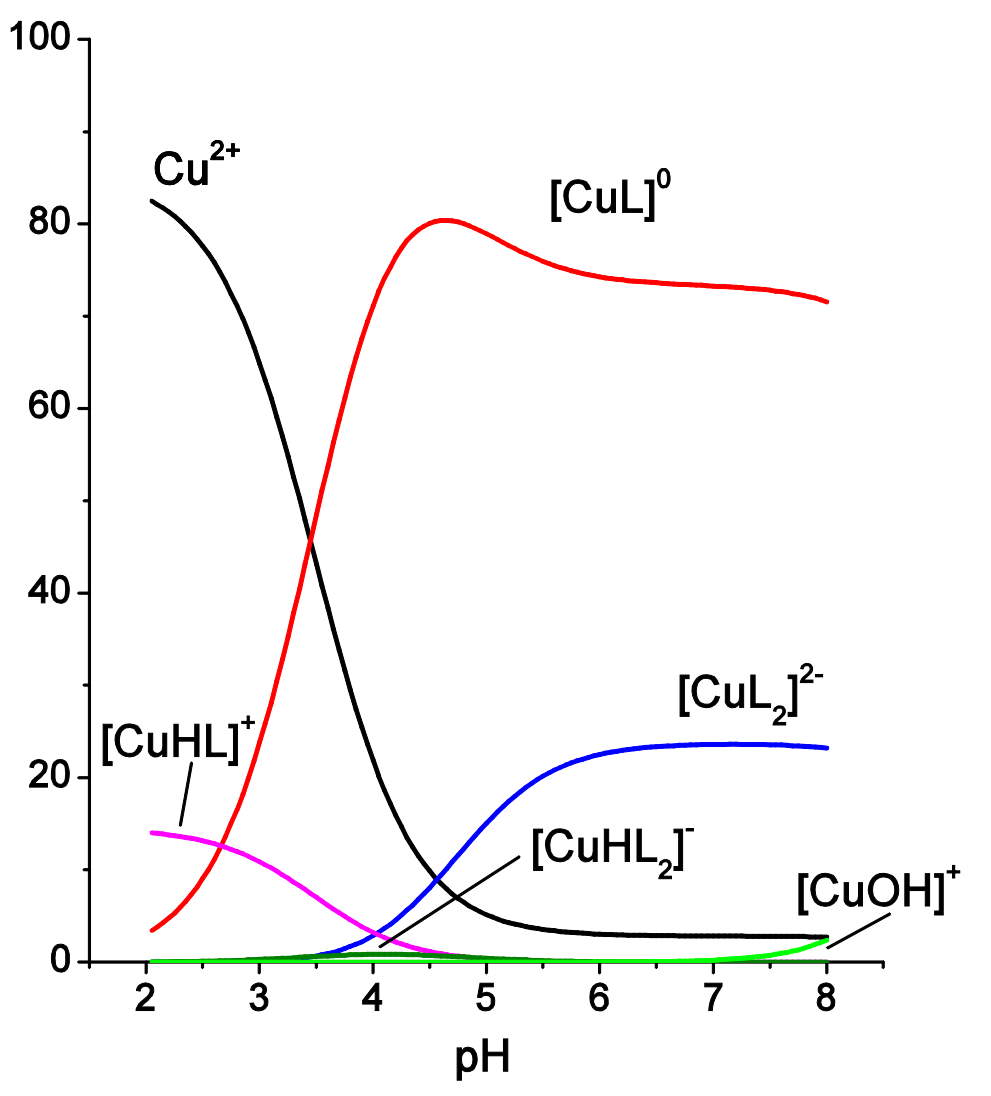

Figure 3. Fraction diagrams for the system of copper(II) - succinic acid as a pH function (I = 0.1 ). 